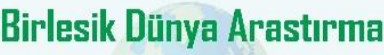 BD-CENTER \\ Global Journal of Foreign Language Teaching}

Innovasyon ve Yayıneilik Merkezi
Volume 10, Issue 1, (2020) 072-085

www.giflt.eu

\title{
An investigation of students' preferences in Japanese teaching and learning
}

Junko Winch*, Sussex Centre for Language Studies, University of Sussex, BN1 9SH Brighton, UK

\section{Suggested Citation:}

Winch, J. (2020). An investigation of students' preferences in Japanese teaching and learning. Global Journal of Foreign Language Teaching. 10(1), 072-085. https://doi.org/10.18844/giflt.v10i1.4571

Received from July 15, 2019; revised from September 18, 2019; accepted from January 24, 2020.

Selection and peer-review under responsibility of Assoc. Prof. Dr. Jesus Garcia Laborda, Alcala University, Spain. ${ }^{\circ} 2020$ United World Centre of Research Innovation and Publication. All rights reserved.

\begin{abstract}
The teachers in the individualist country usually teach students using individualist approach while teachers in the collectivist countries teach students using collectivist approach. However, teachers and students do not usually share the same educational culture in language classrooms. The purpose of this study has two: first, to examine individualist and collectivist characteristics; second, to ascertain the students' teaching preference whether it is individualist or collectivist approach in a British university. Participants were 19 students who study Japanese language through institution wide language program at a British university in the South of England. The collected data consist of two: questionnaire and an informal interview, both of which were conducted at the end of spring term 2019. The data were analysed using mixed methods. The quantitative results showed that students preferred a mixture of both educational cultures. The ratio of individualist: collectivist:neutral position was 74:11:16 in spite of the fact that this study was conducted in an individualist education culture.
\end{abstract}

Keywords: Collectivist, educational culture, higher education, individualist, Japanese learning.

\footnotetext{
* ADDRESS FOR CORRESPONDENCE: Junko Winch, Sussex Centre for Language Studies, University of Sussex, BN1 9SH Brighton , UK.
} E-mail address: dr.junko.winch@gmail.com / Tel: +0-127-387-7409 


\section{Introduction}

Internationalisation and a multicultural learning environment have become the norm at British universities. The students, who study at the British universities from overseas, are committed to their own educational culture and they usually prefer the teaching and learning environment where came from and are familiar with. The problem that I have been encountered in my Japanese language teaching is that there are variety of students' teaching learning preferences and requirements which may be specific to the culture and I am not familiar with. Having educational cultural knowledge would help not only myself, but also other language teachers and students' learning. The purpose of this study is to identify if students who study Japanese language at a British university show any preferences to either individualist or collectivist educational culture. The researcher tries to answer the following specific research question: Do students in this study prefer individualist or collectivist teaching approaches?

This paper starts with a discussion of literature on individualist and collectivist, followed by Methods and the combined Result and Discussion section. Finally, the combined section for 'Conclusion, Recommendation, Limitation and Further study' concludes this paper.

\section{Theoretical framework}

This section starts with the characteristics of individualist cultural characteristics, which is followed by that of collectivist, which becomes a framework of this paper.

\subsection{Individualist culture}

Individualist is defined as 'the interests of the individual prevail over the interests of the group' (Hofstede, Hofstede \& Minkov, 2010, p. 91). There are two key words and philosophers which influence teaching and learning between the West and Confucian countries. In the West, the key word is 'independence' and key philosopher is Socrates. Where sensitivity to the individual is considered of paramount importance in society, one-to-one instruction and one-to-one interaction are ideal. An example of one-to-one instruction is dialogue. Dialogue between student and teacher encourages students' critical thinking. In the dialogue, Socrates plays a role of 'a midwife who helps give birth to a truth that lies within' (Hinkel, 1999, p. 19). Critical thinking is primarily derived from Anglo-European paradigms (Tan, 2017) and has become a practice developed and promoted by Western EnglishSpeaking countries from the 1970 (Vandermensbrugghe, 2004). Therefore, critical thinking is a pedagogy associated with an individualist educational culture (Winch, 2019). Another pedagogy which is valued in an individualist culture is truth (Winch, 2019).

As CLT usually prefers one-to-one interaction, CLT represents one of individualist educational cultural pedagogies. For example, a typical CLT uses pair-work speaking practice, which provides students student-to-student interaction. With pair work, each student can have a one-to-one interaction with his/her partner at their own pace, which is tailored learning. Although the 'learning = being taught' is still promulgated as a dominant approach and by many voices including those of a government (Watkins, 2005), the learning concept of individual sense-making is encouraged in an individualist culture.

According to psychology studies, in an individualist culture, individuals aim to 'influence' (have an impact on, change, improve) their environment to fit their own needs (Morling, Kitayama \& Miyamoto, 2002). To successfully 'influence' or change the physical or social environment, a person must act on others or one's environment (e.g., by expressing an opinion). The main task of a person in an individualist culture is to 'stand out' by becoming distinguished from others through self-sufficiency and personal accomplishment (Elliot, Chirkov, Kim \& Sheldon, 2001, p. 505) so individuals need to promote themselves. The concept of 'influence' can also be observed consistently in a learning environment where students are expected to speak up in class. 
Business studies find that individuals base their identity on their own accomplishments and experience (Merkin, Taras \& Steel, 2014) in individual culture, as it places higher emphasis on reward responsiveness and goal striving in the possibility of reward (Elliot et al., 2001). In human behaviour, there are two approaches: approach goals and avoidance goals (Elliot et al., 2001). Approach goals are preferred in individualist culture (Elliot et al., 2001), which focuses on a positive outcome or state and regulation involves trying to move towards or maintain that outcome or state (e.g., do well in school' 'make friends' (Elliot et al., 2001).

Emphasis on goal striving in an individualist culture also influences human emotional reaction. Psychology studies also find differences in how people would like to feel depending on culture. Tsai, Knutson and Fung (2006) demonstrated that the cultural idea and practices may play a more prominent role in influencing how people would like to feel. Those from an individualist culture tend to experience enthusiasm, excited and energetic (Elliot et al., 2001; Kuppens, 2007; Tsai et al., 2006). Another study by Berzonsky (2011) finds that those who adopt whether individualist or collectivist view process identity style differently when they deal with identity conflicts. Soenens, Berzonsky and Papini (2016, p. 420) also claim that 'individuals with an information style engage in an open, systematic examination of identity options.... when confronted with new and possibly self-discrepant information, they process it in a relatively flexible, unbiased fashion'. They rely on active problem-solving strategies and possess intrinsic goals such as self-development and community contribution (Berzonsky, Cierciuch, Duriez \& Soenes, 2011; Berzonsky, Macek \& Nurmi, 2003; Duriez, Luyckx, Soenens \& Berzonsky, 2012; Soenens, Duriez \& Goossens, 2005). Problem-solving is also one of the key words which relates to critical thinking.

Both business and linguistic studies also find the preferred rhetorical strategies that are used in individualist culture. Individuals in an individualist culture express directly and assertively in both communication and writing style (Charnock, 2010; Kim, 1994). In addition, clarity and reasoned argument (Hammer, 2005; Kaye, 2006) are also preferred. In communication, individualist is demonstrated by more use of ' $I$ ' (Hofstede et al., 2010) than 'we'. In writing, the writer is responsible for direct and explicit constructions of meaning (Charnock, 2010) with emphasis on originality or creativity. Originality is demonstrated in writing by the use of the writer's own words and preferred the 'thesis and argument' (Charnock, 2010) text structure where the writer's idea is expressed.

\subsection{Collectivist culture}

Collectivist is defined as 'the interest of the group prevails over the interest of the individual' (Hofstede et al., 2010, p. 90). This definition extends to collectivist cultural preference in teaching and learning environment. In a collectivist culture, teacher-to-whole group instruction is common, where the teacher looks at a class as one group as a student. The preference for teacher-to-whole group instruction also makes sense why the concept of learning is 'being taught and transmission of knowledge from the teacher'. With this teacher-to-whole group instruction, the pedagogy 'teacher sanctions the students to speak up' works well. Another pedagogy used in a collectivist is turn-taking, which the teacher sanctions all students to equally speak up and participate in the class.

According to psychology study, in a collectivist culture, collectivists aim to 'adjust' (modify, alter, subvert) their environment to fit their own needs (Morling et al., 2002). To successfully adjust his or her own needs to the environment, a person must first assess the demands of the environment (by allowing others to act first, observing where objects are located). The main task of a person in collectivist culture is to 'fit in' by maintaining interpersonal relationship and group harmony (Markus \& Kitayama, 1991).

A sense of belonging is also a collectivist characteristic. A collectivist society consists of collective units such as family, school, work place and nation. People usually belong to more than one unit and they experience a collective culture consistently throughout their lives. Therefore, collectivist cultures discourage independence (Tan, 2017) and prefer dependence and interdependence. To contrast Socrates in the West, Confucius is the influential philosopher: 'Confucius is asked questions by his 
students and respond with wisdom' (Hinkel, 1999, p. 19). Confucius approach fosters a dependent relationship between the teacher and students and encourages passive and uncritical students.

Both business and linguistic studies find that a collectivist culture prefers to express indirectly (Kapoor, Hughes, Baldwin \& Blue, 2003) and vaguely or ambiguously (Kaplan, 1966) in both communication and writing style. In communication, individualist is demonstrated by more use of 'we' (Hofstede et al., 2010) than ' $I$ '. In writing, the writers show respect for their readers by presenting materials without spelling out its relevance (Charnock, 2010) and readers are responsible to understand the meaning by drawing inference from it. Vagueness and ambiguity may be often represented by incoherent writing (Winch, 2018). The writing of a collectivist culture is demonstrated by the use of relevant stories, proverbs and phrases without the need for the writer to explain the intended meanings specifically. The preferred text structure is descriptive, which is demonstrated by the 'background and topic' (Charnock, 2010).

According to Tsai et al. (2006) and Kuppen's (2007) psychology studies, those from collectivist cultures experience calm, relaxed and serene when they feel pleasant. Instead of individualists' active behaviour and goal-pursuit, those who have a collectivist culture feel relaxation, content or 'enjoy the moment' (Kuppens, 2007). Berzonsky's (2011) identity process study shows that individuals in a collectivist society 'do not engage in an intentional personal exploration of values and options, but instead internalise and rely primarily on the norms and prescriptions of significant others. When confronted with new identity-relevant information, they tend to assimilate it into already existing and rigidly held self-views It is claimed that they define themselves mainly in terms of collective selfattribution, reflecting conformity and conservatism (Berzonsky et al., 2011; Duriez et al., 2012; Soenens et al., 2005). They easily experience discrepant information as potentially threatening and are likely to distort, ignore or simply dismiss self-discrepant information (Soenens et al., 2016). As it is claimed that 'with normative style scores high on need for closure, prejudice and right-wing social-political views: define themselves mainly in terms of collective self-attributes such as religion and nationality; and value goals reflecting conformity and conservatism (Berzonsky et al., 2003; Duriez et al., 2012; Soenens et al., 2005). Avoidance goals are preferred in collectivist culture. (Elliot et al., 2001), which focus on a negative outcome or state and regulation involves trying to move or stay away from that outcome or state (e.g., 'not do poorly in school' 'avoid losing friends') (Elliot et al., 2001).

\section{Methodology}

\subsection{Participants}

The total number of sample students was 19 who were learning Japanese in the institution wide language program context in 2018/19. These students consisted two levels of languages: 16 Ab initio students and 3 Advanced 3 students. The selection of the participants for both pilot and substantive study was based on convenience sampling.

The nationalities of the 19 students were: 6 British, 3 Hong Kong, 2 Chinese, 2 German, 1 French, 1 Danish, 1 Greek, 1 Vietnamese, 2 Romanians. Judging from the nationalities, British, German, French and Danish are assumed to be comfortable with individualist culture. Hong Kong, Chinese, Greek, Vietnamese and Romanians may be more comfortable with collectivist culture. However, judging students' culture by nationalities is misguiding to label students' cultures, as all students do not necessarily represent their nationalities. Where the students previously studied and what their parents' nationalities are also influential on how they behave and react in a certain way. For example, a student who has a British nationality, but assigned her ethnicity as Thai indicates that her culture may not be pure British individualist culture. In fact, both of her parents are from Thailand which may influence her somewhat collectivist view. For this reason, the table below is presented to summarise where they were previously educated, students' parents' nationalities and what language they speak as fluent as native speakers if they speak more than two. 


\begin{tabular}{|c|c|}
\hline German 1 & $\begin{array}{l}\text { Educated in Germany whose parents are Arabic and German. Speaks } 3 \text { languages: } \\
\text { German, English and Arabic }\end{array}$ \\
\hline German 2 & $\begin{array}{l}\text { Educated in Germany whose parents are Arabic and German. Speaks English and } \\
\text { German }\end{array}$ \\
\hline British 1 & Educated in the UK whose parents are both Thai \\
\hline British 2 & Educated in the UK whose parents are British and African \\
\hline British 3 & Educated in the UK whose parents are British and African \\
\hline British 4 & Educated in the UK whose parents are British and Spanish \\
\hline Romanian 1 & $\begin{array}{l}\text { Educated in Romania, went to Russian nursery whose parents are both Romanian. } \\
\text { Speaks } 5 \text { languages: Romanian, Russian, Italian, English and French }\end{array}$ \\
\hline Romanian 1 & $\begin{array}{l}\text { Educated in Greece, and the UK, whose parents are both Romanian. Speaks } 3 \text { languages: } \\
\text { Romanian, English and Greek }\end{array}$ \\
\hline Chinese 1 & $\begin{array}{l}\text { Educated in Chinese until junior high school. Went to an international high school in } \\
\text { Singapore, whose parents are both Chinese. Speaks Chinese and English. }\end{array}$ \\
\hline Danish & Educated in the UK whose parents are both Syrian. Speaks Arabic and English. \\
\hline Vietnamese & $\begin{array}{l}\text { Educated in an international school in Vietnam whose parents are both Vietnamese. } \\
\text { Speaks } 3 \text { languages: Vietnamese, English, Spanish }\end{array}$ \\
\hline Greek & $\begin{array}{l}\text { Educated in an international school in Greece whose parents are both Greek. Speaks } \\
\text { Greek and English. }\end{array}$ \\
\hline
\end{tabular}

\subsection{Research design}

This study uses questionnaires which provide quantitative and qualitative data. Since this study includes quantitative methods, details of a fixed design should be addressed. A fixed design incorporates two further designs: experimental and non-experimental (Robson, 2002, p. 87). Informal interview also provides qualitative data. This study should be classified as a mixed-method design and takes a nonexperimental design as 'the researcher does not attempt to change the situation, circumstances or experience of the participants' (Robson, 2002, p. 88).

\subsection{Validity and reliability}

In relation to population external validity (Gliner, Morgan \& Leech, 2009, p. 128), this study is rated low (Gliner et al., 2009, p. 129) as it uses convenience sampling. However, 'external replication' (Graziano and Raulin 2000, p. 201) could be considered as a threat to external validity. It is claimed that researchers are usually interested in either 'a specific finding on its own right', or in the generalisability of their study (Robson, 2002, p. 106). Evaluating replication, this study focuses on a specific finding, that is, a research of students' educational culture who learn Japanese in a British university with a mixture of different nationalities. Therefore, it is difficult to confer any generalised findings from this study.

\subsection{Data collection: questionnaires and interviews}

The questionnaires and informal interview were chosen as data collection tools and considered suitable to identify students' cultural perception. Below are the details of pilot and substantive study.

\subsubsection{Pilot study}

A pilot study questionnaire was conducted during the class on 02/05/2019 using the same participants prior to the present study. Looking at the preliminary results of the pilot study, the researcher discovered some issues in analysing the data, which resulted to changing the format of presenting the questionnaire. 


\subsubsection{Substantive study}

The questionnaires in the present study were administered and collected data during the class on 09/05/2019. The questionnaires consisted of 18 questions to elicit students' preference for individualist or collectivist. Students were asked to tick only one statement either individualist or collectivist. They were also asked to provide their nationalities and any languages they speak as fluent as a native speaker.

Informal interviews were also conducted as a supplement to the questionnaire. The interview was conducted prior to the administration of questionnaire to obtain information on students' previous educational cultural background and students' parents' nationalities/ethnicity and educational culture.

\subsection{Data analysis}

As this study used mixed approaches, both quantitative and qualitative analysis is explained. As for quantitative analysis, the total number of students who agreed with either individualist or collectivist statement for the 18 questions in the questionnaire was counted. Then, the percentage to determine either individualist or collectivist was calculated consistently and systematically for 18 questions. If the number of students who support individualist and collectivist statements were very similar or close (for example, students who support individualist view is $53 \%$ and that of collectivist is $57 \%$ ), this statement is considered as neutral and categorised into the 'neutral position'. Finally, the ratio of individualist: collectivist: neutral position was determined.

The qualitative techniques were also used to analyse the informal interview and students' comments to determine the themes which was discussed in the literature review: noting patterns and themes, seeing plausibility, counting and clustering for classes and categories (Miles \& Huberman, 1994). Student's nationalities were also recorded to compare individualist and collectivist preference for each statement. In addition, students' previous educational cultural background, their current educational culture and their parents' educational culture were also taken into consideration.

\section{Results and discussion}

\subsection{Results}

After the data analysis, following 13 themes had emerged related to the literature review: (1) learning environment; (2) communication strategy; (3) concept of learning; (4) writing style; (5) identity within the culture (6) originality and creativity; (7) teacher-to-whole group interaction versus one-to-one interaction; (8) influence versus adjustment; (9) decision-making; (10) independence versus dependence/interdependence; (11) critical thinking; (12) approach goals versus avoidance goals and (13) sense of belonging.

Learning environment

\begin{tabular}{lll}
\multicolumn{1}{c}{ Q1 } & \multicolumn{1}{c}{ Individualist } & Collectivist \\
\hline They are familiar with the & 74\% (14 out of 19 students) agreed & \\
learning environment where & with this statement, which indicate \\
students individually speak up in & preference for individualist \\
class and they do, too &
\end{tabular}


I express their opinions

indirectly and vaguely. Others

usually have to guess what I

mean. I always think of other

people and harmony and put

their needs to be the second
$26 \%$ (5 out of 19 students, nationalities: 1 German, 2 Chinese, 1 Hong Kongese, 1 British) agreed with this statement, which indicate preference for collectivist

\section{Communication strategy}

\begin{tabular}{|c|c|c|}
\hline Q3 & Individualist & Collectivist \\
\hline $\begin{array}{l}\text { I express myself directly and } \\
\text { assertively. I use dominate } \\
\text { communication even when I } \\
\text { may hurt others }\end{array}$ & $\begin{array}{l}47 \% \text { ( } 9 \text { out of } 19 \text { students, } \\
\text { nationalities: } 2 \text { German, } 1 \text { French, } \\
1 \text { Greek, } 2 \text { Romanian, } 1 \text { Hong } \\
\text { Kongese, } 1 \text { British, } 1 \text { Chinese) } \\
\text { agreed with this statement, which } \\
\text { indicate preference for individualist }\end{array}$ & \\
\hline $\begin{array}{l}\text { I express their opinions } \\
\text { indirectly and vaguely. Others } \\
\text { usually have to guess what I } \\
\text { mean. I always think of other } \\
\text { people and harmony and put } \\
\text { their needs to be the second }\end{array}$ & & $\begin{array}{l}47 \% \text { ( } 8 \text { out of } 19 \text { students, } \\
\text { nationalities: } 1 \text { Danish, } 1 \text { Vietnam, } \\
4 \text { British, } 1 \text { Hong Kongese, } 1 \\
\text { Chinese) agreed with this } \\
\text { statement, which indicate } \\
\text { preference for collectivist }\end{array}$ \\
\hline
\end{tabular}

As two students ( 1 British and 1 Hong Kongese) ticked neither of A or B and the response of individualist and collectivist was close, this response was categorised into neutral position.

\begin{tabular}{lll}
\hline \multicolumn{1}{c}{ Q8 } & \multicolumn{1}{c}{ Individualist } & \multicolumn{1}{c}{ Collectivist } \\
\hline $\begin{array}{l}\text { It is important that self-evident } \\
\text { things must be said explicitly }\end{array}$ & $\begin{array}{l}\text { 63\% (12 out of 19 students, } \\
\text { nationalities: 4 British, 1 Chinese, 1 } \\
\text { French, 1 Romanian, 2 German, 1 } \\
\text { Vietnamese, 1 Hong Kongese, 1 } \\
\text { Danish) agreed with this } \\
\text { statement, which indicate } \\
\text { preference for individualist }\end{array}$ & \\
It is unnecessary to say self- & & $\begin{array}{l}\text { 37\% (7 out of 19 students, } \\
\text { evident things explicitly }\end{array}$ \\
& & $\begin{array}{l}\text { nationalities: 1 Romanian, } 1 \text { Greek, } \\
\text { 2 Hong Kong, 1 Chinese, 2 British) } \\
\text { agreed with this statement, which } \\
\text { indicate preference for collectivist }\end{array}$ \\
\hline
\end{tabular}

\section{Concept of learning}

\begin{tabular}{lll}
\hline \multicolumn{1}{c}{ Q4 } & \multicolumn{1}{c}{ Individualist } & \multicolumn{1}{c}{ Collectivist } \\
\hline $\begin{array}{l}\text { Learning is individual } \\
\text { sense-making }\end{array}$ & $\begin{array}{l}\text { 63\% (12 out of 19 students, } \\
\text { nationalities: } 5 \text { British, 2 German, } \\
\text { 1 French, 1 Danish, 2 Hong Kong, } \\
\text { 1 Romanian) agreed with this } \\
\text { statement, which indicate } \\
\text { preference for individualist }\end{array}$ & \\
$\begin{array}{l}\text { Learning is being taught } \\
\text { and transmission of } \\
\text { knowledge from the } \\
\text { teacher }\end{array}$ & & $\begin{array}{l}\text { 37\% (7 out of 19 students, } 1 \text { Greek, } 2 \\
\text { Chinese, 1 Romanian, 1 Vietnamese, } 1 \text { Hong } \\
\text { Kong, 1 British) agreed with this statement, } \\
\text { which indicate preference for collectivist }\end{array}$ \\
\hline
\end{tabular}


One Romanian student commented that learning takes places in two stages, the first goes through the transmission stage and then the second, individual sense-making stage.

\section{Writing style}

\begin{tabular}{ll}
\hline \multicolumn{1}{c}{ Q5 } & \multicolumn{1}{c}{ Individualist } \\
\hline Students think it is more & C2\% (8 out of 19 students, \\
important to express their & nationalities: 1 British, 1 German, \\
opinions rather than describing & 1 Hong Kong, 1 Romanian, 2 \\
background and topic in their & Chinese, 1 French, 1 Greek) agreed \\
written coursework & with this statement, which \\
& indicate preference for \\
& individualist
\end{tabular}

Students prefer to describe background and topic rather than expressing their opinions in their written coursework
$53 \%$ (10 out of 19 students, nationalities: 4 British, 1 Vietnamese, 1 German, 2 Hong Kong, 1 Danish, 1 Romanian) agreed with this statement, which indicate preference for collectivist

As one British student ticked neither A or B and the number of $A$ and $B$ are close response of individualist and collectivist was close, this response was categorised into a neutral position.

\begin{tabular}{lll}
\hline \multicolumn{1}{c}{ Q16 } & \multicolumn{1}{c}{ Individualist } & \multicolumn{1}{c}{ Collectivist } \\
\hline $\begin{array}{l}\text { Readers are responsible for } \\
\text { understanding what the writer } \\
\text { means and also should infer the } \\
\text { writers' intention }\end{array}$ & $\begin{array}{l}42 \% \text { (8 out of 19 students) agreed } \\
\text { with this statement, which } \\
\text { indicate preference for collectivist }\end{array}$ \\
$\begin{array}{l}\text { Writers are responsible to make } \\
\text { sure that readers understand what } \\
\text { they have written }\end{array}$ & $\begin{array}{l}58 \% \text { (11 out of } 19 \text { students) } \\
\text { agreed with this statement, which } \\
\text { indicate preference for } \\
\text { individualist }\end{array}$ & \\
\hline
\end{tabular}

\section{Identity within the culture}

\begin{tabular}{|c|c|c|}
\hline Q6 & Individualist & Collectivist \\
\hline $\begin{array}{l}\text { I have confidence in my own } \\
\text { abilities and that they think they } \\
\text { need to promote myself to others }\end{array}$ & $\begin{array}{l}26 \% \text { ( } 5 \text { out of } 19 \text { students, } \\
\text { nationalities: } 1 \text { French, } 2 \text { British, } 1 \\
\text { Hong Kong, } 1 \text { German) agreed } \\
\text { with this statement, which } \\
\text { indicate preference for } \\
\text { individualist }\end{array}$ & \\
\hline $\begin{array}{l}\text { Even if I feel confident, I feel that I } \\
\text { should not boast themselves and } \\
\text { they tend to say the opposite }\end{array}$ & & $\begin{array}{l}74 \% \text { ( } 14 \text { out of } 19 \text { students, } \\
\text { nationalities: } 4 \text { British, } 1 \text { Greek, } 2 \\
\text { Chinese, } 2 \text { Romanian, } 2 \text { Hong } \\
\text { Kongese, } 1 \text { Vietnamese, } 1 \text { German, } \\
1 \text { Danish) agreed with this } \\
\text { statement, which indicate } \\
\text { preference for collectivist }\end{array}$ \\
\hline
\end{tabular}

Q7 Individualist Collectivist


It is normal in their country to use someone's ideas, proverbs, stories and phrases without referencing to make a point and persuade readers The knowledge is never fixed and that they construct knowledge through individual contribution by questioning the received wisdom
21\% (4 out of 19 students, nationalities: 2 Hong Kongese, 1 Chinese, 1 Romanian) agreed with this statement, which indicate preference for collectivist

$79 \%$ (15 out of 19 students) agreed with this statement, which indicate preference for individualist

\section{One-to-whole group interaction versus one-to-one interaction}

Q10 Individualist

\section{Collectivist}

I accept individual differences and they like class tasks which place emphasis on individuals

$89 \%$ (17 out of 19 students) agreed with this statement, which indicate preference for individualist

I like classes where a teacher looks at all the student as one group

$16 \%$ (3 out of 19 students) agreed with this statement, which indicate preference for collectivist

One British student ticked both A and B. More students supported individualist than collectivist view on this topic.

Influence versus adjustment

\begin{tabular}{ll}
\hline \multicolumn{1}{c}{ Q13 } & \multicolumn{1}{c}{ Individualist } \\
\hline $\begin{array}{l}\text { We should act on others and stand } \\
\text { through personal accomplishment }\end{array}$ & $53 \%$ (10 out of 19 students, \\
& $\begin{array}{l}\text { Greek, 2 Romanian, } 2 \text { Hong } \\
\text { Kongese, 1 Vietnamese, } 1\end{array}$ \\
& $\begin{array}{l}\text { German) agreed with this } \\
\text { statement, which indicate } \\
\text { preference for individualist }\end{array}$
\end{tabular}

I am happy to modify their aims

and wishes to fit in to an

institution or workplace

$47 \%$ (9 out of 19 students, nationalities: 4 British, 1 German, 2 Chinese, 1 Hong Kongese, 1 Danish) agreed with this statement, which indicate preference for collectivist

As the total number of responses for individualist and collectivist statements was close, this response was categorised into a neutral position.

\section{Decision making}

\begin{tabular}{lll}
\multicolumn{1}{c}{ Q12 } & \multicolumn{1}{c}{ Individualist } & \multicolumn{1}{c}{ Collectivist } \\
\hline $\begin{array}{l}\text { I make my decision based on } \\
\text { their personal values, goals, self- } \\
\text { development or community } \\
\text { contribution }\end{array}$ & $\begin{array}{l}\text { 58\% (11 out of 19 students, } \\
\text { nationalities: 2 British, 2 } \\
\text { Romanians, 1 Greek, 2 Hong Kong, } \\
\text { 1 French, 1 German, 1 Vietnamese, } \\
1 \text { Chinese) agreed with this } \\
\text { statement, which indicate } \\
\text { preference for individualist }\end{array}$ & \\
$\begin{array}{l}\text { when I make decision, I tend to } \\
\text { rely primarily on norms and } \\
\text { prescriptions of their family or }\end{array}$ & & $\begin{array}{l}\text { 42\% (8 out of 19 students, } \\
\text { nationalities: } 4 \text { British, } 1 \text { Danish, } 1 \\
\text { Chinese, } 1 \text { German, } 1 \text { Hong } \\
\end{array}$ \\
\hline
\end{tabular}


Winch, J. (2020). An investigation of students' preferences in Japanese teaching and learning. Global Journal of Foreign Language Teaching. 10(1), 072-084. https://doi.org/10.18844/gjflt.v10i1.4571

people who are important to

them statement, which indicate

preference for collectivist 
Independence versus dependence/interdependence

\begin{tabular}{|c|c|c|}
\hline 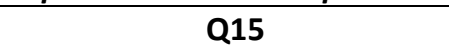 & Individualist & Collectivist \\
\hline I am independent learners & $\begin{array}{l}74 \% \text { (14 out of } 19 \text { students) agreed } \\
\text { with this statement, which indicate } \\
\text { preference for individualist }\end{array}$ & \\
\hline $\begin{array}{l}\text { I am dependent on teachers in } \\
\text { learning }\end{array}$ & & $\begin{array}{l}21 \% \text { ( } 4 \text { out of } 19 \text { students) agreed } \\
\text { with this statement, which indicate } \\
\text { preference for collectivist }\end{array}$ \\
\hline Q17 & Individualist & Collectivist \\
\hline $\begin{array}{l}\text { In my culture, independence } \\
\text { is emphasised }\end{array}$ & $\begin{array}{l}68 \% \text { (13 out of } 19 \text { students) agreed } \\
\text { with this statement, which indicate } \\
\text { preference for individualist }\end{array}$ & \\
\hline $\begin{array}{l}\text { In my culture, dependence } \\
\text { and interdependence is } \\
\text { encouraged }\end{array}$ & & $\begin{array}{l}26 \% \text { ( } 5 \text { out of } 19 \text { students, } \\
\text { nationalities: } 2 \text { Chinese, } 2 \text { Hong } \\
\text { Kong, } 1 \text { Romanian) agreed with this } \\
\text { statement, which indicate } \\
\text { preference for collectivist }\end{array}$ \\
\hline
\end{tabular}

\section{Critical thinking}

Q9

I am a critical thinker.

I do not know what critical

thinking is and I have not been

trained to think critically in

their previous education

\section{Individualist}

$84 \%$ (16 out of 19 students) agreed with this statement, which indicate preference for individualist

\section{Collectivist}

$11 \%$ ( 2 out of 19 students) agreed with this statement, which indicate preference for collectivist

One British student ticked neither individualist nor collectivist statement.

\section{Approach goals versus Avoidance goals}

\begin{tabular}{|c|c|c|}
\hline Q18 & Individualist & Collectivist \\
\hline $\begin{array}{l}\text { I hope that I do well in } \\
\text { Japanese modules (Approach } \\
\text { goals) }\end{array}$ & $\begin{array}{l}74 \% \text { (14 out of } 19 \text { students) agreed } \\
\text { with this statement, which indicate } \\
\text { preference for individualist }\end{array}$ & \\
\hline $\begin{array}{l}\text { I hope that I don't fail in } \\
\text { Japanese modules (Avoidance } \\
\text { goal) }\end{array}$ & & $\begin{array}{l}26 \% \text { ( } 5 \text { out of } 19 \text { students) agreed } \\
\text { with this statement, which indicate } \\
\text { preference for collectivist }\end{array}$ \\
\hline Q2 & Individualist & Collectivist \\
\hline $\begin{array}{l}\text { I feel pleasant and happy, } \\
\text { they get excited and } \\
\text { enthusiastic }\end{array}$ & $\begin{array}{l}42 \% \text { ( } 8 \text { out of } 19 \text { students) agreed } \\
\text { with this statement, which indicate } \\
\text { preference for individualist }\end{array}$ & \\
\hline $\begin{array}{l}\text { When I feel pleasant and } \\
\text { happy, they feel relaxed, at } \\
\text { ease, content or enjoy the } \\
\text { moment }\end{array}$ & & $\begin{array}{l}58 \% \text { ( } 11 \text { out of } 19 \text { students, } \\
\text { nationalities: } 4 \text { British (include } 1 \text { RA), } \\
1 \text { German, } 1 \text { Vietnamese, } 1 \text { French, } 2 \\
\text { Hong Kongese, } 1 \text { Danish, } 1 \text { Romanian) } \\
\text { agreed with this statement, which } \\
\text { indicate preference for collectivist }\end{array}$ \\
\hline
\end{tabular}




\section{Sense of belonging}

\begin{tabular}{|c|c|c|}
\hline & Individualist & Collectivist \\
\hline $\begin{array}{l}\text { I think that Japanese classes } \\
\text { have family-like ties with } \\
\text { classmates }\end{array}$ & $\begin{array}{l}47 \% \text { ( } 9 \text { out of } 19 \text { students) did not } \\
\text { agree with this statement, which } \\
\text { indicate preference for individualist }\end{array}$ & \\
\hline $\begin{array}{l}\text { I think that Japanese classes } \\
\text { have family-like ties with } \\
\text { classmates }\end{array}$ & & $\begin{array}{l}53 \% \text { (10 out of } 19 \text { students, } \\
\text { nationalities: } 3 \text { Hong Kongese, } 2 \\
\text { Chinese, } 1 \text { German, } 1 \text { Vietnamese, } \\
1 \text { British, } 1 \text { Danish, } 1 \text { Romanian) } \\
\text { agreed with this statement, which } \\
\text { indicate preference for collectivist }\end{array}$ \\
\hline
\end{tabular}

As the response of individualist and collectivist was close, this response was categorised into neutral position.

\subsection{Discussion}

According to Winch's (2013) study, students' teaching and learning preferences were categorised into the following three types: Type 1 consisted of students who came from a collectivist educational cultural background and were now studying in an individualist educational culture. Type 2 covered students from an individualist educational cultural background continuing to study in an individualist educational culture. Type 3 comprised of students from an individualist educational cultural background but who were also subject to a degree of collectivist influences (this was often the case where their parents are from a collectivist educational cultural background) studying in an individualist educational culture. As the researcher was also a teacher of the class, the researcher also replicated Winch's (2013) previous study. However, the results of this study showed the following five types (one of them includes two sub-types) of students:

Type 1 consisted of students who came from a collectivist educational cultural background and were now studying in an individualist educational culture. In this study, further two sub-types were identified, that is, Type 1i) and Type 1ii). Type 1i) is those who have no previous experience in studying in an individualist educational culture until studying at this university and this is their first time they have studied in individualist educational culture. Four students were applicable to Type 1i) in this study; Type 1ii) is those who have experienced individualist educational culture at international high school prior to coming to this University, which gives students an individualist educational experience. Three students of this study were categorised as Type 1ii).

Type 2 covered students who come from an individualist educational cultural background and continue to study in an individualist educational culture. Type 2 is the only students who do not encounter cultural differences nor need to experience adjustment of culture. Three students were categorised as Type 2 .

Type 3 comprised students from an individualist educational cultural background but who may be also under influence of collectivist influence (this is often the case where both of their parents are from a collectivist educational cultural background). Two students of this study were categorised as Type 3. In addition to above three types, two new types of students were identified in this study.

Type 4 is the students who are familiar with the individualist educational culture but were also subject to a degree of collectivist influence. This is often the case where one of their parents is from a collectivist cultural background (e.g., his/her father is from an individualist cultural background, whereas his/her mother is from a collectivist cultural background). Five students in this study were categorised as Type 4.

Type 5 is the students who are familiar with the individualist educational culture but had influences from studying and living in other collectivist and individualist countries and cultures where they have 
lived and are able to speak those languages fluently. They are usually multilingual students. Two students were categorised as Type 5 .

\section{Conclusion, recommendation, limitations and further study}

The results show that the ratio of individualist: collectivist: neutral was 74:11:16, despite that this study was conducted in a British individualist university. Among 19 statements in the questionnaire, 14 individualist statements ( $74 \%$ of the total statements) were agreed by the majority on: creativity, emphasis of clarity, critical thinking, 'learning as sense-making', 'emphasis on individuals', 'decision making', 'responsibility of reader and writer', 'writing style', independence and approach goals. Only two collectivist statements ( $11 \%$ of the total statements) on 'preference for vague communication strategy' and 'feeling pleasant is relaxed, at ease and enjoy the moment' were preferred by the majority. The results on 'influence versus adjustment', 'indirect and vague communication' and 'sense of belonging' were categorised into the neutral positions.

The recommendation is to disseminate the educational cultural knowledge to students in the teacher education program who will become teachers in the future. The findings in this study should also benefit the future teachers to understand students' diverse teaching and learning preferences and requirements.

The main limitation was the low number of participants. The total number of participants in this study was 19 , which is a relatively small sample size. It was not feasible to increase the size of participants, as this was the maximum number of students in this study. This limits the generalisability of the conclusions drawn from the results. Nonetheless, it may be possible to find results on this specific sample population. The second limitation is on methodology. In developing the questionnaire, the researcher inferred and provided the potential answers as the participants' choices. However, a full understanding of students' perceptions and feelings may not necessarily be gained from the questionnaire because the options included by the researcher may have limited the responses. Furthermore, there is always a danger that the students might not provide their honest opinions in the questionnaire and also that the interpretation of the data may be culturally biased to obtain the unanimous interpretation compared to quantitative method.

As for the suggested further study, the opposite of this study, that is, to examine whether students from multicultural background studying in a collectivist country prefer collectivist teaching approach would be interesting to compare similarities or differences of students' between individualist and collectivist culture as this study concerned about a Japanese language class in a British university which examines whether students from multicultural background studying in an individualist country prefer an individualist teaching approach.

\section{References}

Berzonsky, M. D. (2011). A social-cognitive perspective on identity construction. In S. J. Schwartz, K. Luyckx \& V. L. Vignoles (Eds.), Handbook of identity theory and research (vol. 1, pp. 55-76). New York, NY: Springer.

Berzonsky, M. D., Cierciuch, J., Duriez, B. \& Soenens, B. (2011). The how and what of identity formation: Assoiations between identity styles and value orientations. Personality and Individual Differences, 50, 295-299.

Berzonsky, M. D., Macek, P. \& Nurmi, J. E. (2003). Interrelationships among identity process, content and structure: A cross-cultural investigation. Journal of Adolescent Research, 18, 112-130.

Charnock, K. (2010). The right to reticence. Teaching in Higher Education, 15(5), 543-552. doi:10.1080/ 13562517.2010.491907

Duriez, B., Luyckx, K., Soenens, B. \& Berzonsky, M. D. (2012). A process-content approach to adolescent identity formation: Examining longitudinal associations between identity styles and goal pursuits. Journal of Personality, 80, 135-161. 
Elliot, A. J., Chirkov, V. I., Kim, Y. \& Sheldon, K.M. (2001). A cross-cultural analysis of avoidance(relative to approach) personal goals. Psychological Science, 12, 505-510.

Gliner, J. A., Morgan, G. A. \& Leech, N. L. (2009), Research methods in applied settings-an integrated approach to design and analysis. New York, NY: Routledge.

Hammer, M. R. (2005). The Intercultural Conflict Style Inventory: A conceptual framework and measure of intercultural conflict resolution approaches. International Journal of Intercultural Relations, 26(5), 551575. https://doi.org/10.1016/j.ijintrel.2005.08.010

Hinkel, E. (1999). Culture in second language teaching and learning. Cambridge, UK: Cambridge University Press.

Hofstede, G., Hofstede, G. J. \& Minkov, M. (2010). Cultures and organizations - Software of the mind. New York, NY: McGraw-Hill Book Company.

Kaplan, R. B. (1966). Cultural thought patterns in inter-cultural education. Language learning, 16(1\&2), 1-20. doi:10.1111/j.1467-1770.1966.tb00804.x

Kapoor, S., Hughes, P. C., Baldwin, J. R. \& Blue, J. (2003). The relationship of individualism -collectivism and selfconstrual's to communication styles in India and the United States, International Journal of Intercultural Relations, 27(6), 683-700.

Kaye, D. L. (2006). International students as (un)bounded sojourners: Emergent articulations of culture and identity through intercultural communication. Carbondale, IL: Southern Illinois University Press.

Kim, M. S. (1994). Cross cultural comparison of the perceived importance of conversation constraints. Human Communication Research, 21, 128-151.

Kuppens, P. (2007). Individual differences in the relationship between pleasure and arousal. Journal of Research in Personality, 42, 1053-1059. https://doi.org/10.1016/i.jrp.2007.10.007

Markus, H. \& Kitayama, S. (1991). Culture and the self: Implications for cognition, emotion and motivation. Psychological Review, 98, 224-253. doi:10.1037/0033-295X.98.2.224

Merkin, R., Taras, V. \& Steel, P. (2014). State of the art themes in cross-cultural communication research: A systematic and meta-analytic review. International Journal of Intercultural Relations, 38, 1-23. doi.org/10.1016/j.ijintrel.2013.10.004

Miles, M. B. \& Huberman, A. M. (1994), Qualitative data analysis. London, UK: Sage publications.

Morling, B., Kitayama, S. \& Miyamoto, Y. (2002). Cultural pracies emphasize influence in the United States and adjustment in Japan. Personality and Social Psychology Bulletin, 28, 311-323.

Sukhnandan, L. \& Lee, B. (1998). Streaming, setting and grouping by ability: a review of the literature. Slough, UK: Slough National Foundation for Educational Research (NFER).

Soenens, B., Duriez, B. \& Goossens, L. (2005). Social-psychological profiles of identity styles: Attitudinal and social - cognitive correlates in late adolescence. Journal of adolescence, 8, 107-125.

Soenens, B., Berzonsky, M. D. \& Papini, D. R. (2016). Attending to the role of identity exploration in self-esteem: Longitudinal associations between identity style and two features of self-esteem. International Journal of Behavioural Development, 40(5), 420-430.

Tan, C. (2017). Teaching critical thinking: Cultural challenges and strategies in Singapore. British Educational Research Journal, 43(5), 987-1002.

Tsai, J. L., Knutson, B. \& Fung, H. H. (2006). Cultural variation in affect valuation. Journal of Personality and Social Psychology, 90, 288-307.

Vandermensbrugghe, J. (2004). The unbearable vagueness of critical thinking in the context of Anglo-Saxonisation of Education. International Education Journal, 5(3), 417-421.

Watkins, C. (2005). Classrooms as learning communities: a review of research. London Review of Education, 3(1), 47-64. https://doi.org/10.1080/14748460500036276

Winch, J. (2013). An investigation of the impact of Japanese educational culture: Japanese language learning in an international context. Saarbrucken, Germany: Lap Lambert Academic Publishing.

Winch, J. (2018). Academic infractions of assessed work in Japanese language. Global Journal of Foreign Language Teaching, 8(2), 102-112. https://sproc.org/ojs/index.php/GJFLT/article/view/3373

Winch, J. (2019). Does communicative language teaching help develop students' competence in thinking critically. Journal of Language and Education, 5(2), 112-122. http://sro.sussex.ac.uk/id/eprint/70649 